\title{
The effect of copper on cadmium-tolerant lawn grass
}

Gladkov E.A. ${ }^{1,2}$, Gladkova O.N. ${ }^{3}$

${ }^{1}$ Timiryazev Institute of Plant Physiology Russian Academy of Sciences, Moscow, Russia; ${ }^{2}$ Moscow Institute of Physics and Technology, Moscow, Russia; ${ }^{3}$ Moscow State University of Environmental Engineering, Moscow, Russia

E-mail: gladkovu@mail.ru

Key message. Cadmium -tolerant plants were more resistant to copper. However, the increase in resilience was not very significant. Therefore, it is more expedient to obtain plants that are resistant to copper.

Keywords: copper, cadmium, lawn grasses, Agrostis stolonifera

Lawn grasses are highly sensitive to heavy metals. Therefore, increasing resistance to heavy metals is essential in urban greening, ornamental horticulture and in agriculture. Agrostis stolonifera L. grass has an advantage over many other lawn grasses because it is capable of vegetative reproduction and permits to create lawn for different purposes only from itself. The lawn from Agrostis stolonifera does not need to be cut often, it withstands a shadowing and relatively resistant to gases. Previously, plants of Agrostis stolonifera were obtained that are resistant to cadmium using cell selection. However, plants that are resistant to one environmental factor may be cross-resistant to another. Therefore, the aim of this work was to assess the tolerance of the next generation descendants of the regenerant Agrostis stolonifera, resistant to cadmium, to one of the most phytotoxic heavy metals - copper. Copper is one of the priority pollutants of ecosystems. Copper enters the soil from various sources - emissions from vehicles, industrial plants, fertilizers, some solutions for spraying various crops, household and municipal waste. The cross-resistance of descendants of the next generation of the regenerant to copper was assessed by the inhibition of shoot growth in aqueous solutions of the toxicant. The degree of resistance of the cadmium -tolerant plants was compared with the original plants. Cadmium -tolerant plants showed more resistance to copper compared to the original plants at all the tested concentrations. However, the increase in resistance was not significant (for example, at a copper concentration of $50 \mathrm{mg} / \mathrm{l}$, the growth of the original plants was $61 \%$ of the control, $74 \%$ of the control were resistant to cadmium). Thus, plants obtained by cell selection, resistant to cadmium, had a higher resistance to copper, but this resistance is insufficient at a high level of pollution. Therefore, it is more expedient in conditions of a high level of copper pollution to obtain plants that are resistant to this metal.

\section{Влияние меди на газонные травы, толерантные к кадмию \\ Гладков Е.A. ${ }^{1,2}$, Гладкова O.H. ${ }^{3}$}

${ }^{1}$ ФГБУН Институт физиологии растений им. К.А. Тимирязева РАН, Москва, Россия; ${ }^{2}$ Московский физикотехнический институт, Москва, Россия; ${ }^{3}$ Московский государственный университет инженерной экологии, Москва, Россия

\begin{abstract}
Аннотация. Растения, толерантные к кадмию продемонстрировали большую устойчивость к меди. Однако, повышение устойчивости не было очень значительным. Поэтому более иелесообразным является получение растений, устойчивых кмеди.
\end{abstract}

Ключевые слова: медь, кадмий, газонные травы, Agrostis stolonifera

Газонные травы обладают повышенной чувствительностью к тяжелым металлам. Поэтому повышение устойчивости к тяжелым металлам имеет важное значение в городском озеленении, декоративном садоводстве и в сельском хозяйстве. Объект исследования - газонная трава полевица побегоносная (Agrostis stolonifera L.). Данное растение имеет ряд преимуществ - вегетативно размножается за короткий срок, отсутствие необходимости частой стрижки, теневыносливость, возможность создания газона разного назначения только из полевицы побегоносной. Газон из полевицы побегоносной относительно газоустойчив. Ранее были получены растения Agrostis stolonifera, устойчивые к кадмию с помощью клеточной селекции. Однако, растения, устойчивые к одному экологическому фактору, могут обладать перекрестной устойчивостью к другому. Поэтому целью работы была оценка толерантности потомства одного из регенерантов Agrostis stolonifera, устойчивого к кадмию, к одному из наиболее фитотоксичных тяжелых металлов - меди. Медь - один из приоритетных загрязнителей экосистем. Медь поступает в почву из различных источников - выбросы автотранспорта, промышленных предприятий, удобрения, некоторые растворы для опрыскивания различных сельскохозяйственных культур, бытовые и коммунальные отходы. Перекрестную устойчивость к меди оценивали по ингибированию роста побегов в водных растворах токсиканта. Степень устойчивости потомков регенеранта сравнивали с исходными растениями. Растения, толерантные к кадмию продемонстрировали большую устойчивость к меди, по сравнению с исходными растениями, при всех исследуемых концентрациях. Однако, повышение устойчивости не было значительным (например, при концентрации меди 50 мг /л рост исходных растений составлял $61 \%$ от контроля, устойчивых к кадмию $74 \%$ от контроля). Таким образом, растения, толерантные к кадмию, полученные с помощью клеточной селекции, обладали большей устойчивостью к меди, однако, этой устойчивости недостаточно при высоком уровне загрязнения. Поэтому более целесообразным в условиях высокого уровня загрязнения медью является получение растений, устойчивых к этому металлу. 